\title{
Salesperson's Customer Orientation: A Reconceptualization and a New Definition
}

\section{Ramendra Singh \\ Abraham Koshy}

\section{W.P. No.2008-04-01}

April 2008

The main objective of the working paper series of the IIMA is to help faculty members, research staff and doctoral students to speedily share their research findings with professional colleagues and test their research findings at the pre-publication stage. IIMA is committed to maintain academic freedom. The opinion(s), view(s) and conclusion(s) expressed in the working paper are those of the authors and not that of IIMA.

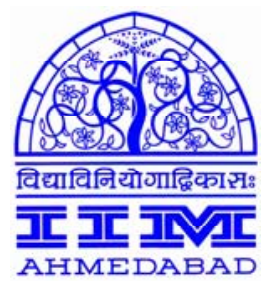

INDIAN INSTITUTE OF MANAGEMENT

AHMEDABAD-380 015

INDIA 


\title{
Salesperson's Customer Orientation: A Reconceptualization and a New Definition
}

\author{
Ramendra Singh ${ }^{1}$ \\ Abraham Koshy ${ }^{2}$
}

\begin{abstract}
This study critically examines the existing domains, conceptualizations and operationalizations of the salesperson's customer orientation constructs present in the literature. The widely used Salesperson orientation-Customer orientation (SOCO) construct (its domain, definition and scale) is examined in detail, and several inconsistencies were found. We also examine other individual-level and organizationallevel orientation constructs, including market orientation, in order to appropriately delineate the boundaries of the salesperson's customer orientation construct. Based on a comprehensive review of literature on the marketing concept, and related literatures on several other relevant orientation constructs, we suggest a new definition of this mid-level construct. Not only is our new definition more encompassing (to include all activities of the salesperson related to customers, and not just their interactions with the customers) but is also more forward-looking (salesperson's enhanced role not just as need-fulfiller, but more as customers' value co-creator). We sincerely hope that the new definition suggested by us would encourage scale development efforts from researchers, that would aid in further reducing (if not removing)the several inconsistencies present in the literature related to salespersons' customer orientation, and its effect on their performance and effectiveness.
\end{abstract}

\footnotetext{
${ }^{1}$ Doctoral Student (Marketing), IIM Ahmedabad (Email: ramendras@iimahd.ernet.in)

${ }^{2}$ Professor (Marketing), IIM Ahmedabad (Email : koshy@iimahd.ernet.in)

The authors would like to thank Raj Agnihotri for the valuable suggestions made on an earlier draft of this paper.
} 


\section{Salesperson's Customer Orientation: A Reconceptualization and a New Definition}

\section{Introduction}

The marketing concept, considered to be a cornerstone of the marketing thought, calls for an integrated, firm-level approach, where all of the firm's activities are directed toward providing customer satisfaction and establishing mutually beneficial, long-term relationships with its market (Kotler 1980). From the marketing concept emerge the concept of customer-oriented selling, which Saxe and Weitz (1982) define as the practice of the marketing concept at the level of the individual salesperson and customer. However, customer orientation in personal selling as a concept is not new. More than 80 years ago, Strong (1925) emphasized that personal selling strategies should be oriented toward securing customer satisfaction, and not just purchase orders. Latter researchers have reinforced the concept in personal selling literature e.g. Kurtz, Dodge, and Klompmaker (1976) suggest that, " Sales personnel no longer specialize solely in increasing sales volume; rather, the prospect's real needs become the basis of the marketing plan. A mark of professionalism in sales is that sellers adopt a problem-solving approach to their work, A professional salesperson does not wonder, 'What can I sell this individual?" but instead asks, "How can I best solve this person's problems?'” (p, 13, 14).

Much of the personal selling literature widely accepts the conceptualization of the salesperson's customer orientation construct given by Saxe and Weitz (1982), which is defined by them as 'the degree to which he or she practice(s) the marketing concept by trying to help his or her customers make purchase decisions that will satisfy customer needs' (p. 344), although the marketing concept itself has not been defined. We argue that the current conceptualization of salesperson's customer orientation suffers from being too narrowly focused on satisfaction of customer needs. Moreover the marketing concept itself has not been properly delineated in Saxe and Weitz's (1982) definition. This calls for revisiting the domain of the salesperson's customer orientation as a construct to properly delineate the boundaries of the construct and provide a more comprehensive and encompassing definition. We also hope that the new conceptualization will contribute towards reducing some of the anomalies existing in the literature regarding customer orientation and its subsequent impact on salesperson's performance and effectiveness. 
With this objective, the rest of the paper is laid out as follows:

- We first, critically evaluate the conceptualization of the construct suggested by Saxe and Weitz (1982) and also other conceptualizations in the literature.

- Then we look at the shortcomings of the operationalization of Saxe and Weitz's (1982) construct i.e. SOCO scale and also other operationalization in the literature.

- We follow it up with the review of the extant literature on other orientations at individual level to see how it can contribute towards reconceptualizing the construct of salesperson's customer orientation. Some of these would be:

o Market orientation and Customer orientation as its dimension

o Task, Self and People orientations

o Learning and Performance goal orientations

o Relationship marketing orientation

o Service and service quality orientation

o Work related orientations

- Finally based on the review of the relevant literature, we propose a new definition of the salesperson's customer orientation. We do this by appropriately delineating its boundaries and making the definition more comprehensive in scope by focusing not just on the salespersons' role as need fulfiller, but as a co-creator of value with customers to keep them satisfied through mutually benefiting long term relationships.

\section{Conceptualization Issues}

Saxe and Weitz (1982) have defined salesperson's customer orientation as the practice of the marketing concept at the level of the individual salesperson and customer. However the authors have not clearly specified, what constitutes a marketing concept, and whether it is a philosophy, a set of activities or a strategy. Moreover as discussed later, the salesperson's customer orientation cannot be confined to only the salesperson-customer interaction. Instead, we argue that, it should encompass all activities of the salespersons, 
which ultimately lead to successfully, and continuously creating value for them by meeting their latent customer needs and keeping them satisfied. Among other definitions of salesperson's customer orientation is that of Brown et al. (2002) who conceptualise it based on two dimensions: meeting customer needs and enjoyment. They define customer orientation as employees' tendency to meet customer needs and the extent to which they enjoy doing so. As is evident, the conceptualization of Brown et al. (2002) is even narrower than that of Saxe and Weitz (1982).

Early researchers also suggest that customer orientation would lead to low pressure selling (Bursk 1947) and a need satisfaction and problem solving approach (Gwinner 1968). Moreover Saxe and Weitz (1982) suggest that the selling concept in a company corresponds to a low level of customer orientation in a salesperson.

\section{Operationalization Issues}

Barrett (1972) suggests that even though there may be several reasons for different researchers to arrive at varying conclusions, one of the greatest difficulties in survey research is assuring the accuracy of measurement of the constructs under examination. Even with such techniques as meta-analysis, strong conclusions often cannot be drawn from a body of research due to problems with measurement (Schmidt et al.1985). Observing true covariance between the variables is dependent on the ability to accurately and reliably operationalize the unobservable construct (Hinkin 1985). Literature on salesperson's customer orientation is largely inconsistent in its findings, and we would make an attempt to list out some plausible ways in which these inconsistencies can be correctly attributed to not only the conceptualization issues but also the operationalization weaknesses of the SOCO construct.

\section{Limitations of SOCO as a measure of salesperson's customer orientation}

One of the earliest and most widely used scales for measuring selling orientation of salespeople is the 24 items (12 positively worded and 12 negatively worded items) SOCO (Sales Orientation-Customer Orientation) scale developed by Saxe and Weitz (1982). Since then several studies have modified the SOCO scale to suit the context of their studies. While some studies have reduced the scale to lesser number of items to reduce 
respondent fatigue and acquiescence bias (e.g. ten item scale used by Thomas, Soutar, and Ryan 2001), others have changed the rater of the scale from salesperson to customer and adapted for b2b context (e.g. Michaels and Day 1985). Periatt et al. (2004) cross validated the revised SOCO scale proposed by Thomas, Soutar, and Ryan (2001), and established the generalizability of the revised scale. Few others have changed the response format from the original 9 point scale to 7 point scale (e.g. Tadepalli 1995), or even the original scale anchors ranging from "true for none of the customers" to "true for all customers" to verbal anchors ranging from "strongly disagree" to "strongly agree"(e.g. Tadepalli 1995). This has lead to inconsistent empirical findings in the salesperson's customer orientation literature.

SOCO scale and its derivative scales focus on selling orientation vs. customer orientation and fail to incorporate the reality that an individual (salesperson) may actually possess varying degrees of both types of orientation, and use it depending on the sales situations. From this perspective these two constructs are not a part of the same continuum as suggested by the SOCO scale. Thomas, Soutar, and Ryan (2001) have empirically shown that these two constructs are "distinct, although related" (p. 67), and correlated $(\mathrm{r}=.53$ ) and $(r=.61)$ for two distinct samples. Brown et al. (2002) also demonstrated that the measures separated into two distinct factors. Customer orientation was defined as employees' tendency to meet customer needs and the extent to which they enjoy doing so. Selling orientation was defined as a focus on activities that may result in sales in the short term at the expense of customer satisfaction (Saxe and Weitz 1982). Thus SOCO has severe shortcoming as a valid measure of a salesperson's customer orientation. However the interesting question to ask is that if a particular salesperson is found to be high on selling orientation as well high on customer orientation as measured by SOCO, as the two dimensions are distinct, then what does it mean? Does it mean that the salesperson possesses and uses either of these two orientations effectively as and when required? The reasons why salespeople can be expected to be high on both $\mathrm{SO}$ and $\mathrm{CO}$ is that they probably use both of these orientations as situations may demand. This premise is congruent to the findings of the adaptive selling literature. Since more adaptive selling behaviors are likely to lead to higher sales effectiveness, we conjecture that highly effective salespersons are more likely to exhibit higher degree or level of both SO and CO. However validating this conjecture, either conceptually through arguments or empirically, is beyond the scope of this study. 
Another shortcoming of the SOCO is that of the delineation of the boundaries of the construct. Since customer orientation of the salespersons as defined by them focuses on need identification and fulfillment with an objective of helping customers in their purchase decisions, the ability of the construct to predict salesperson's performance should be consistent and high. Instead, the evidence from the literature presents an inconsistent picture related to customer orientation of salespersons as measured by the SOCO scale and salespersons' performance.

While few studies have found a strong association between customer-oriented selling and salespersons' performance (e.g. Brady and Cronin 2001; Goff et al. 1997; Kelley 1992; Langerak 2001; Reicheld and Sasser 1990; Saxe and Weitz, 1982), others have reported no significant association between the two constructs (e.g. Howe, Hoffman, and Hardigree 1994). Even factoring for the inconsistencies in conceptualization and operationalization of the salespersons' performance construct, the salesperson's customer orientation's ability to explain variance in salesperson's performance is limited. Jaramillo et al. (2007) notes that the SOCO scale manages to explain only about two percent of the overall variance in salesperson job performance. Recently, a meta-analytic study by Franke and Park (2007) reflected the same thought when they noted that :

\begin{abstract}
"Apparently, though, customer-oriented selling does not consistently lead to sales or other results that managers value, because its effects on manager-rated and objective performance are nonsignificant. Salespeople may believe that customer-oriented selling has long-term benefits, even if their short-term results are not recognized by managers or reflected in objective sales measures" (p. 700).

"Therefore, the meta-analysis raises questions about how effectively customer-oriented selling implements the marketing concept at the salesperson-customer level (Saxe and Weitz1982)" (p. 700).
\end{abstract}

This leads Donavan, Brown, and Mowen (2004) to raise caution when extrapolating the positive relationship between customer orientation and salespersons' performance under all environmental situations, and suggest a need to establish "boundary conditions" of customer orientation. We now discuss the boundary conditions of the salesperson's customer orientation construct. 


\section{Boundary Conditions}

Salesperson's customer orientation has been also dealt with by many researchers from its boundary conditions, albeit indirectly. Several studies (e.g. Weitz 1979) have argued that salesperson's behaviors must be tailored to individual customers since their actions in specific selling situations ultimately determine their success. Literature on adaptive selling suggests that effective salespeople work smarter rather than harder (e.g. Sujan 1986; Dixon et al 2001) and enacting a learnt set of appropriate behaviors increases the probability of goal attainment (e.g. Solomon et al 1985; Lichtenstein and Brewer 1980; Leigh and McGraw 1989). This points to few boundary conditions of salesperson's customer orientation, and suggests that the final objective of salespersons' customer orientation is not just to better understand the customer needs and preferences but to ultimately attain the goal of serving those needs by selling their company's products and services.

\section{Other Orientations in Literature}

\section{Goal Orientation}

Literature on educational psychology, as well as sales literature has focused on two types of goal orientations: learning (or mastery) goals and performance (or ego) goals (Dweck 1986; Kohli, Shervani, and Challagalla 1998; Sujan, Weitz, and Kumar 1994; VandeWalle et al. 1999). Individual-level goal orientations have been also shown to influence workplace behaviors (Kohli et al. 1998). In the sales context, a learning goal orientation motivates salespeople to enjoy the process of learning and apply it to increase their achievement (Sujan, Weitz, and Kumar 1994). Salespeople with learning goal orientation are intrinsically motivated to complete a difficult task and are generally unconcerned about their performance relative to others, prefer challenging tasks, acquire new skills and experiences, show persistence and enhanced effort in the face of failure, and demonstrate an overall positive affect toward learning (Kohli, Shervani, and Challagalla 1998; Sujan, Weitz, and Kumar 1994; VandeWalle et al. 1999). In contrast, salespeople with a performance goal orientation are most interested in demonstrating their ability in relation to others, without any concern for the intrinsic value of the task. Thus the distinction between the two constructs is in terms of improving ability (learning 
orientation) vs. demonstrating ability (performance orientation) and both possess the characteristics of traits as well as states (Button et al 1996) and thus amenable to influence by psychological antecedents. Harris et al (2005) empirically demonstrate that learning orientation positively influences customer orientation, and performance orientation positively influences selling orientation. Kohli et al. (1998) suggest that salespersons with a learning orientation may be keen to develop skills that are beneficial in the long term and to spend more time with difficult customers, even at the cost of forgoing short-term results. Similarly, Vandewalle et al. (1999) suggest that the learning orientation should be most appropriate for building customer service competencies, since it leads salespeople to enjoy the process of selling effectively (Sujan et al. 1994), and persist in challenging sales situations (Kohli et al. 1998). Although sales environment may influence the orientations of the salespersons, literature in psychology suggests that orientations are relatively stable and individuals may possess varying degrees of each orientation (Sujan et al 1994; Vandewalle and Cummings 1997).

\section{Task, Interaction and Self-Orientations}

In an organizational context, Bass (1967) have suggested two important orientations that impact the employees' performance, behaviors and relationships: task orientation and interaction orientation. Task-orientation (TO) is defined as the extent to which the employee is concerned about completing a job, solving problems, working persistently and doing the best job possible. Task-orientation was seen originally as characteristic of persons who in social settings, "will try ... hardest to help obtain the group's goals, solve its problems, overcome barriers preventing the successful completion of the group's tasks, and who persist at ... assignments.”(Bass 1960a, p.149). Typical preferences would include:

- To have the feeling of a job well done.

- To have bright, interesting friends.

- To be wise.

- To work at a hobby.

- To be a leader who gets things done. 
Interaction-orientation (IO) on the other hand, is defined as the extent of concern with maintaining happy, harmonious personal relationships-interest in-group activities is high. Interaction-orientation was defined initially as characteristic of a person who consistently is, "concerned with the group as a means for forming friendships, sharing things with others, providing the security of "belonging," and helping foster strong interpersonal relationships.” (Bass, 1960a, p.149). Typical preferences would include:

- To have fun with friends.

- To have helpful friends.

- To work cooperatively.

- To make more friends.

- To be an easy-to-talk-to leader.

Ray (1973) suggests that a task-oriented individual is likely to be more tolerant of deviant opinion, conflicting ideas, directive supervision, give less attention to interpersonal relations and thus is more likely to be isolated and less popular than an interaction oriented individual. In more recent literature, task orientation (Harvey and Novicevic, 2001) and people orientation (Jordan and Cartwright, 1998) refer to the extent to which individuals are involved or motivated to attain the assigned goals and interact with other people at work. These are analogous to initiating structure (emphasis on task accomplishment) and consideration (emphasis on concern for individuals and groups) dimensions of leader behaviors (Van Seters and Field 1990). Drawing an analogy with the SOCO scale, a selling orientation is closer to the task orientation, while customer orientation is closer to the interaction or people orientation.

Bass (1960a) further distinguishes between self-orientation, from task orientation and interaction orientations. According to Bass, self-orientation has been defined as characteristic of a person who is, "More concerned about his own needs than those of others ... more interested in extrinsic reward than intrinsic satisfaction of work ... [the group] is the cast as well as the audience before which the self-oriented member can air his personal difficulties, gain in status or esteem, aggress or dominate." (Bass, 1960a, p. 149-150). Typical preferences would include: 
- To be recognized for efforts.

- To have loyal friends.

- To receive personal praise.

- To take it easy.

- To be a respected leader.

Customer orientation is seemingly closely associated with interaction orientation and less closely associated with self and task orientation.

\section{Service Orientation}

One of the popular constructs in services marketing is that of service orientation, which has been well researched at individual as well as firm level. At an individual level the construct has been defined as, "a set of attitudes and behaviors affecting the quality of interaction between an organisation's employees and its customers" (Hogan et al., 1984, p. 167). Hogan et al. (1984) developed a 92-item scale (SO), to measure the concept derived from the service orientation index (SOI), suggested by Hogan's personality inventory (HPI). Several other studies have also used service-quality orientation (e.g. Camarero 2007) to conceptualize and operationalise the service quality dimensions suggested by Grönroos (1993) consisting of functional service quality (trained employees, efficient service) and technical service quality (technologies, professionalism). Yet another scale is SERV*OR developed by Lytle et al (1998) that incorporates dimensions such as services aspects, customers treatment and employee empowerment.

\section{Relationship Marketing Orientation}

Similarly another construct somewhat similar to customer orientation is relationship marketing orientation (RMO) developed by Sin et al (2005) that measures the extent to which a company engages in developing a long-term relationship with its customers. RMO is viewed as a philosophy of doing business successfully or as a distinct organizational culture/value that puts the buyer-seller relationship at the centre of the firm's strategic or operational thinking (Sin et al., 2002). This one-dimensional construct has six behavioral components- bonding, empathy, reciprocity, shared value, 
communication, and trust--that can be measured reliably with a multi-item scale (Sin et al. 2002). Relationship marketing itself has been defined as, "attracting, maintaining, and enhancing customer relationships" Berry (1983,p. 25). Grönroos (1991) defines it as attempts by firms to establish, maintain, and enhance relationships with customers and other parties at a profit so that the objectives of all the parties are met by mutual exchange and fulfillment of promises. Relationship orientation at the organizational level pervades all parts of the organization's mind-set, values, and norms that impact all interaction with the customer - before, during, and after the sale (Day, 2000). Jayachandran et al. (2005) further affirm that customer-relationship orientation establishes a "collective mind" or a belief system in the organization, which values customer relationships as assets and drives the choice of processes to accomplish it.

\section{Work Related Preferences: People Dimension}

Similarly in the work related literature, Pryor (1982) outlined a conceptual framework for linking needs, values, preferences, work ethics, and orientations to work. To further account for the individual differences in work, Pryor (1987) subjected the Work Aspect Preference Scale (WAPS; Pryor, 1983b, Pryor 1979) to investigate how people may differ across dimensions as well as along them. The 52-item WAPS scale containing 13 subscales was analyzed and found to have three second order factors: non-work orientation (Detachment, Life Style, and Money as subscales), freedom (Creativity, SelfDevelopment, Independence, and Management as subscales) and people concern (Altruism, Coworkers, and Security as subscales). This three factor structure of work related preferences is similar to Environment-People-Self trichotomy suggested by Lofquist and Dawis (1978), and Mortimer's (1975) three-factor structure: Extrinsic, SelfExpression, and People. Drawing comparisons with the salesperson's customer orientation construct, the customer orientation is closely related to the high people concern for all the three trichotomies mentioned above.

\section{Review of Past Conceptualizations}

Before we conceptualize the salesperson's customer orientation construct, we would following the guidelines suggested by Clark and Watson (1995), first review the previous attempts to conceptualize and assess both the same construct as well as the closely related 
constructs with a perspective to specify not only what a construct is, but also what it is not.

Literature on interpersonal behavior models suggests two dimensions, concern for self and concern for others (Blake and Mouton 1970; Buzzotta, Lefton, and Sherberg 1972; Thomas 1976). Saxe and Weitz (1982) suggest that customer orientation is related to the 'concern for others' dimension. They further suggest that high customer orientation would be closely associated with high concern for self as well as for others, where as low customer orientation would be closely associated with high concern for self, but low concern for others.

Research on individual level customer orientation is divided into two streams-personal selling literature (e.g., Brown, Widing, and Coulter 1991; Kennedy, Lassk, and Goolsby 2002; Saxe and Weitz 1982) and services marketing literature (e.g., Brady and Cronin 2001; Brown, Mowen, Donnavan, and Licata 2002). In personal selling, a salesperson's customer orientation has been defined as 'the degree to which he or she practice(s) the marketing concept by trying to help his or her customers make purchase decisions that will satisfy customer needs' (Saxe and Weitz 1982, p. 344). A customer-oriented salesperson aims to uncover and satisfy these latent needs and, 'avoid actions which sacrifice customer interest to increase the probability of making an immediate sale' (Saxe and Weitz 1982, p. 344). Saxe and Weitz (1982) identified the following seven characteristics of customer orientation based on previous literature review and field interviews of 25 sales managers:

1. A desire to help customers make satisfactory purchase decisions.

2. Helping customers assess their needs

3. Offering products that will satisfy those needs

4. Describing products accurately

5. Adapting sales presentations to match customer interests.

6. Avoiding deceptive or manipulative influence tactics

7. Avoiding the use of high pressure.

According to Thomas, Soutar, and Ryan (2001), characteristics that distinguish customeroriented selling from other selling approaches include: salesperson's desire to assess 
customer needs, avoid high-pressure selling, avoid deception, describe products and services adequately, and helping customers make satisfactory purchase decisions. Brown et al. (2002) define salesperson's customer orientation as an "employee's tendency or predisposition to meet customer needs in an on-the-job context" (p. 111).

Salesperson's customer orientation has also been viewed as an emotional investment that acts as a strong motivator, which in turn is associated with higher levels of performance (Brown et al., 1997). It is also considered a learned behavior that can be influenced by environmental factors, an adaptation that evolves over time (Saxe and Weitz 1982; Williams and Wiener 1990). Stock and Hoyer (2005) have determined that there are two dimensions of customer orientation, attitudinal and behavioral, and that customeroriented attitudes have a direct effect on customer satisfaction.

In a b2b context, Widmier (2002) found that personality variables such as perspectivetaking and empathic concern positively impacted customer orientation of salespersons. On the other hand, job tenure had negative effects on customer orientation. Selfmonitoring, gender, and selling experience were not significantly related to salespeople's level of customer orientation, though few earlier studies have found gender and selling experience to be positively associated with salespeople's customer orientation (e.g.Scheibelhut and Albaum 1973;Siguaw et al 1995;O'Hara et al 1991). Salesperson's customer orientation is also affected by their organization's customer orientation (Cross et al. 2007). Joshi and Randall (2001) empirically found that organizational controls, such as process and outcome controls also impacted salesperson's customer orientation via affective commitment of the salesperson. In a recent study Brown et al. (2002) provided evidence to suggest that salesperson's customer orientation is a surface-level personality trait, and found that deeper personality traits e.g. emotional stability and agreeableness influence salesperson customer orientation. Other possible determinants of customeroriented behavior at the individual level include job satisfaction (e.g., Bateman and Organ 1983; Hoffman and Ingram 1991), leader behavior (Jones, Busch, and Dacin 2003), organizational control (Joshi and Randall 2001), market orientation of the company (Jones et al. 2003; Mengüç 1996), personal traits (Brown et al. 2002), and employee's affect (Peccei and Rosenthal 1997, 2000). 
Organization-level customer orientation, as a concept was developed by Levitt (1960), who defined it in terms of its bottom-line objectives and suggested that a firm's ultimate aim is to achieve customer satisfaction. It was later developed as customer-oriented culture in marketing and strategy literature (e.g. Day and Wensley, 1983; Dean and Bowen, 1994; Day 1994; Noble, Rajiv and Kumar, 2002). A firm may have a customer orientation as one of the dimensions of its strategic orientation, which exhibits its commitment to incorporate customer preferences into its products and marketing processes (Gatignon and Xuereb 1997). The extant literature on market orientation of firms explicitly or implicitly includes the customer orientation. e.g. Narver and Slater's (1990) conceptualization of market orientation includes: customer orientation, competitor orientation, and inter-functional coordination; on the other hand, Kohli and Jaworski (1990) and Kohli, Jaworski, and Kumar (1993)'s conceptualization includes gathering and disseminating information on customer, competitor, and technology and implementing subsequent response.

\section{Review of Past Operationalizations}

Despite being widely embraced for studies in various cultures and contexts, the scales developed for marketing orientation, of which customer orientation is a facet (explicitly or implicitly), suffer from poorly defined domain and weak validity issues (Gauzente 1999). For example MKTOR (scale developed by Narver and Slater) suffers from overemphasis on customer orientation (Kohli, Jaworski, and Kumar 1993). Similarly MARKOR (developed by Kohli, Jaworski, and Kumar) is based on set of activities and behaviors while defining the construct of market orientation as a business philosophy, and suffers from weak factor structure and poor psychometric properties (Farrell and Oczkowski 1998). The third measure of market orientation by Ruekert (1992, p.228) defines the construct as:“...the degree to which the business unit: (i) obtains and uses information from customers; (ii) develops a strategy which will meet customer needs; (iii) implements that strategy by being responsive to customers' needs and wants." As evident, the construct is defined actually for customer orientation rather than market orientation at the firm level. Even of the twenty-three items used to measure market orientation by Ruekert (1992), only two concern competitors or competitiveness. However a content analysis of the MARKOR and MKTOR scales by Gauzente (1999) throws up these customer related themes: attitudes concerning clients (MKTOR), needs and wants of 
customers, customer satisfaction, changes screening and scanning, time management (regular meetings, surveys), department behaviors within the whole organization (MARKOR). Also there is general agreement in the literature that a profit orientation is a consequence of a market orientation, rather than being its part (Farrell 2002). However a more recent definition by Slater and Narver underlines the cultural nature of the market orientation phenomenon as well its profitability implications (Slater \& Narver 1995) while bridging the gap between the construct definition and measure. The revised definition is: "market orientation is the culture that (1) places the highest priority on the profitable creation and maintenance of superior customer value while considering the interest of other key stakeholders; and (2) provides norms for behavior regarding the organizational development and responsiveness to market information" (Slater \& Narver 1995; p67). A meta-analytic study by Deshpande and Farley (1996) proposed a reduced market orientation scales that focus only on customer-related activities.

There have been several other attempts to either refine the existing market orientations scales or come out with new measures (e.g. Pelham 1997; Lado, Olivares and Rivera 1998; Deng and Dart, 1994;Gray et al 1998). A content analysis of the measure of customer orientation dimension of the market orientation scale developed by Narver and Slater (1990) and Deng and Dart (1994) suggests the following themes: understanding and meeting customer needs, listening to and addressing customer comments, complaints and concerns, after-sales service, commitment to customer, increased sales effort to keep customers satisfied, and increased value to customers delivered through products. Items for the scales discussed in this study are provided in the Appendix.

The measure developed by Deshpande, Farley and Webster (1993) in fact sets out to measure market orientation, but actually measures customer orientation. In a latter attempt to come out with a more parsimonious scale, Deshpande and Farley (1998) develop a ten-item scale MORTN that focuses on customers. However as Farrell (2002) points out this scale falls short of meeting the call given by Narver and Slater (1998, p. 236) to incorporate critical behaviors that create superior value for customers such as: (1) a business being clear to its value discipline and value proposition; (2) a business leading its targeted customers by discovering and satisfying their latent needs and not merely responding to their expressed needs; (3) a business seeing and managing itself as a service business; (4) a business managing its targeted customers as customers for life. 


\section{Synthesis of Customer Orientation Literature}

Despite the conceptual distinction between market orientation and customer orientation has been established in the literature (Jones et al., 2003), several researchers still consider these as interchangeable concepts (e.g.Shapiro, 1988; Webster, 1988; Nwankwo, 1995; Deshpande', 1999; Deshpande' et al., 1993; Hartline et al., 2000; Brady and Cronin, 2001), where the term "market" is the set of an organisation's actual and potential customers. Synthesis of different market orientation approaches presented by Lafferty and Hult (2001), demonstrate that there are five basic perspectives for conceiving market orientation as:

(1) Decision taking (Shapiro, 1988);

(2) Market intelligence (Kohli and Jaworski, 1990);

(3) Perspective based on behavioral culture (Narver and Slater, 1990);

(4) Strategic perspective (Ruekert, 1992; Webster, 1992); and

(5) Customer perspective (Deshpande' et al., 1993).

A slightly different stream, yet recent literature on b2b selling have examined buyersupplier relationships from a just-in-time (JIT) philosophy, and extended that to selling function (e.g. Dixon, 1992, 1998a, 1999; Greenblatt, 1993; Frazier et al.1988; Germain et al., 1994). Green et al. (2008) in a recent study, conceptualize JIT-selling as a construct and define it as the seller's, "ability to build value throughout the selling process based on organizational capabilities to deliver zero-defect quality, zero variance quantity, precise on-time delivery and the ability to minimize total waste and total cost throughout the production and marketing processes and exhibits the ability to develop single-source, onsite relationships with customers" (p 139). The JIT selling scale developed by Green and associates has four scales based on dimensions such as, Single-Source Relationships, Purchasing Process Integration, Product and Service Quality Scale, and Inventory Minimization. 


\section{Domain of the Salesperson's Customer Orientation Construct}

\section{Characteristics of a Sound Construct}

A construct, or a theoretical concept, has been defined as an abstract entity that represents the 'true' nonobservable state or nature of a phenomenon (Bagozzi and Fornell 1982). Edwards \& Bagozzi (2000) define it as "a conceptual term used to describe a phenomenon of theoretical interest" (pp 156-157).

Psychological constructs are ordered hierarchically at different levels of abstraction or breadth (Comrey, 1988; John, 1990; Watson, Clark, \& Harkness, 1994). Since constructs can be conceptualized at any level of abstraction, hence a key issue to be resolved is the scope or generality of the target construct (Clark and Watson 1995). Although constructs can be either narrow-band, mid-level or broad in its generality, Clark and Watson's (1995) study found that most recently developed psychological assessment based constructs have be either narrow-band (e.g. Cocaine Expectancy Questionnaire) or midlevel (e.g. Social Phobia and Anxiety Inventory) constructs. However, irrespective of the level of abstraction of the construct, it should be embedded in a theoretical framework (Clark and Watson 1995). Moreover, measures of even the same basic phenomenon will vary with the theoretical perspective of the developer (Loevinger 1957).

According to McGuire (1989), all constructs can be conceptualized in terms of a focal object [O] (physical or perceptual) and a dimension of judgment (or "attribute") [A]; to these the COAR-SE theory of scale construction posited by Rossiter (2002) adds a third term, the judges or rater(s) (or "rater entity")[R]. Thus according to the COAR-SE theory, the construct should be defined (or described) in terms of all three: O-A-R.

Specifically for the salesperson's customer orientation, there is evidence that salespersons tend to overrate themselves, averaging about 8 [on the 1 to 9 (low to high) scale], compared with industrial customers' ratings of them, which average about 6 on the scale (Michaels \& Day, 1985). Thus it become imperative to recognize that the rater of the scale is an inherent part of the construct and hence as mentioned above, salesperson's and customer's rating for salesperson's customer orientation becomes two different scales, 
according to the COAR-SE theory. Thus we define the object, attribute and rater for the construct of our study as follows:

- Object: Salespersons of industrial products

- Attribute: Salesperson's customer orientation

- Rater: Salesperson (individual rater)

According to COAR-SE theory, objects and attributes may be concrete if there is a general agreement on what the object is, and abstract if it means differently to different people. According to this broad classification, since customer orientation as an attribute means different things to different people, it is abstract in nature. The focal object, the salespersons of industrial products, would tend to be more, concrete-abstract. As for its scope or generality, our proposed construct of salesperson's customer orientation is a mid-level construct.

\section{Proposed Definition of Salesperson's Customer Orientation}

Based on the above review of extant literature on customer orientation and other related orientation constructs, it is found that the existing measure of salesperson's customer orientation using the SOCO scale and its various derivative scales does not delineate the salesperson's customer orientation construct holistically. Currently the construct's domain excludes such important aspects as creating customer value, building long-term customer relationships, emphasis on services before-during and after sales, and increased efforts to understand and meet latent customer needs.

Sethi and King (1994) suggest that the first step in building sound constructs is to delineate its domain properly. Thus we delineate the domain of the salesperson's customer orientation construct, based on the above review of the literature, and derive the following seven sub-domains of the construct:

1. Gathering and disseminating relevant information to customers.

2. Understanding the expressed and latent needs of customers.

3. Fulfilling the customer needs continuously.

4. Creating value for customers by delivering superior quality of offerings. 
5. Building long-term relationship with customers.

6. Keeping company's profitability objectives in mind.

7. Keeping customers satisfied.

Based on the above seven sub-domains of the construct, we provide a new definition of the construct, as given below:

\begin{abstract}
“Salesperson's customer orientation is the set of behaviors displayed by salespersons in all customer-related activities that pertain to gathering and disseminating information to customers, understanding their expressed and latent needs, and continuously fulfilling these needs by delivering superior quality products and services through sustained long term relationship with customers, to profitably create value for customers and keep them satisfied."
\end{abstract}

\title{
Directions for Future Research
}

Consistent with the view in literature that customer orientation at an individual level is a surface trait (Brown et al. 2002), we also suggest incorporating salespersons' surface traits in defining their customer orientation. A surface trait describes individual differences that influence behavior within the context of a specific situation. These traits are contextual, and are classified as traits since they are an enduring tendency to behave, within a particular situational context (Brown et al. 2002). Similarly Mowen and Spears (1999) also suggest that a particular situational context may trigger role demands of a job and exert pressures on the employee to behave in specific ways. These situational pressures combine with more basic personality traits to create the surface traits, which is consistent with the established view in the literature that situations interact with dispositions to influence behavior (e.g., Bowers 1973; Endler and Rosenstein 1997).

With this new definition, we hope that future researchers would make an attempt to develop scales to measure the salesperson's customer orientation and make it more aligned to the expected role requirements of the salespersons. Marketing as a discipline is 
increasingly becoming more and more forward looking and value co-creation is fast becoming the next cornerstone of the discipline. 


\section{References}

Bagozzi, R.P., and C.Fornell (1982), "Theoretical Concepts, Measurements, and Meaning," in C.Fornell (Ed.), A Second Generation of Multivariate Analysis, 2, Praeger, 24-38.

Barrett, G.V. (1972), "New Research Models of the Future for Industrial and Organizational Psychology, Personnel Psychology, 25, 1-17.

Bass, B. M. (1960a), Leadership, Psychology and Organizational Behavior, New York: Harper.

Bateman, Thomas S., and Dennis W. Organ (1983),"Job Satisfaction and the Good Soldier: The Relationship between Affect and Employee Citizenship," Academy of Management Journal, 36 (4), 587-595.

Bass, B. M. (1967), "Social Behavior and the Orientation Inventory: A Review," Psychological Bulletin, 68, 260-292.

Berry, Leonard L. (1983), "Relationship Marketing," in Emerging Perspectives on Services Marketing, L.L. Berry, G.L. Shostack, and G.D. Upah, eds. Chicago: American Marketing Association, 25-28.

Blake, R. R., and J. S. Mouton (1970), The Grid for Sales Excellence. New York: McGraw-Hill Book Company.

Bowers, Kenneth S. (1973), "Situationism in Psychology: An Analysis and a Critique," Psychological Review, 80 (September), 307-36.

Brady M.K., and J.Cronin Jr. (2001), "Customer Orientation: Effects of Customer Service Perceptions and Outcome Behaviors," Journal of Service Research, 3(3):241 - 51.

Brown T.J., J.C. Mowen, D.T.Donavan, and J.W.Licata (2002), "The Customer Orientation of Service Workers: Personality Trait Effects on Self- and Supervisor Performance Ratings," Journal of Marketing Research, 34(February): 110-9.

Brown, Steven P., William L.Cron, and John W.Slocum Jr. (1997), "Effects of GoalDirected Emotions on Salesperson Volitions, Behavior, and Performance: A Longitudinal Study," Journal of Marketing, 61(January), 39-50.

Brown, Gene, Robert E. Widing, and Ronald L. Coulter (1991),"Customer Evaluation of Retail Salespeople Utilizing the SOCO Scale: A Replication, Extension, and Application," Journal of the Academy of Marketing Science, 19(4), 347-351.

Bursk, E. C. (1947), "Low-Pressure Selling," Harvard Business Review, 25 (Winter), 227-42. 
Button, Scott, John E. Mathieu, and Dennis M. Zajae (1996), "Goal Orientation in Organizational Behavior Research: A Conceptual and Empirical Foundation," Organizational Behavior and Human Decision Processes, 67 (1), 26-48.

Buzzotta, V. R., R. E. Lefton, and M. Sherberg (1972), Effective Selling Through Psychology. New York: John Wiley \& Sons, Inc.

Camarero, Carmen (2007), "Relationship Orientation or Service Quality?: What is the Trigger of Performance in Financial and Insurance Services?," The International Journal of Bank Marketing, 25(6), 406-426.

Churchill Jr., G. A. (1979), "A Paradigm for Developing Better Measures of Marketing Constructs," Journal of Marketing Research,16(1), 64- 73.

Clark, Lee Anna, and David Watson (1995), "Constructing Validity: Basic Issues in Objective Scale Development," Psychological Assessment, 17(3), 309-319.

Comrey, A. L. (1988), "Factor-Analytic Methods of Scale Development in Personality and Clinical Psychology," Journal of Consulting and Clinical Psychology, 56, 754-761.

Cross, Mark E., Thomas G Brashear, Edward E. Rigdon, and Danny N.Bellenger (2007), "Customer Orientation and Salesperson Performance," European Journal of Marketing, 41(7/8), 821-835.

Day, G.S. (2000), "Managing Market Relationships", Journal of the Academy of Marketing Science, 28(1), 24-30.

Day, G.S. (1994), "The Capabilities of Market-driven Organizations," Journal of Marketing 58(October), 35-52.

Day, G.S. and R.Wensley (1983), "Marketing Theory with a Strategic Orientation," Journal of Marketing 47(Fall), 79-89.

Dean, J. and D.Bowen (1994), "Management Theory and Total Quality: Improving Research and Practice through Theory Development," Academy of Management Review 19(3), 392-418.

Deng, S., and J.Dart J.(1994), "Measuring Market Orientation: A Multi-factor, Multi-item Approach", Journal of Marketing Management, 10, 725-742.

Deshpande', R., and J.U.Farley (1999), "Understanding Market Orientation. A Prospectively Designed Meta-Analysis of Three Market Orientation Scales", in Desphande', R. (Ed.), Developing a Market Orientation, Sage, Thousand Oaks, CA, 217 35.

Deshpande, Rohit and John U, Farley (1996), "Understanding Market Orientation: A Prospectively Designed Meta-Analysis of Three Market Orientation Scales," Marketing Science Institute Working Paper Report No. 96-125. Cambridge, MA: Marketing Science Institute. 
Deshpande, R., and J.U. Farley (1998), "Measuring Market Orientation: Generalization and Synthesis" Journal of Market Focussed Management, 2, 213-232.

Deshpande, R., J.U.Farley, and F.E. Webster (1993), "Corporate Culture, Customer Orientation, and Innovativeness in Japanese Firms: a Quadrad Analysis," Journal of Marketing, 57, 23-37.

Dixon, Andrea L., Rosann L.Spiro, and Maqbul Jamil (2001), "Successful and Unsuccessful Sales Calls: Measuring Salesperson Attributions and Behavioral Intentions," Journal of Marketing, 65(3), 64-78.

Dixon, L. (1999), “JIT II: Ultimate Customer-Supplier Partnership,” Hospital Materiel Management Quarterly, 20(3), 14-20.

Dixon, L. (1998a), “American Corrugated Sells JIT II,” Purchasing, 125(4), 30.

Dixon, L. (1992), “JIT II: A New Approach to Supply Management," Center for Quality of Management Journal, 1(1), 15-18.

Donavan, D. Todd, Tom J. Brown and John C. Mowen (2004), "Internal Benefits of Service-Worker Customer Orientation: Job Satisfaction, Commitment, and Organizational Citizenship Behaviors," Journal of Marketing, 68(1), 128-146.

Dweck, C. S. (1986), "Motivational Processes Affecting Learning," American Psychologist, 41(10), 1040-1048.

Edwards, J. R., and R.P.Bagozzi (2000), "On the Nature and Direction of Relationships between Constructs and Measures," Psychological Methods, 5(2), 155-174.

Endler, Norman S. and Alvin J. Rosenstein (1997), "Evolution of the Personality Construct in Marketing and Its Applicability to Contemporary Personality Research," Journal of Consumer Psychology, 6 (I), 55-66.

Farrell, Mark (2002), "A Critique of the Development of Alternative Measures of Market Orientation, Marketing Bulletin, 13, 1-13.

Farrell, M.A., and E.Oczkowski (1997), "An Analysis of the MKTOR and MARKOR Measures of Market Orientation: An Australian Perspective”, Marketing Bulletin, 8, 3040 .

Franke, George R., and Jeong-Eun Park (2006), "Salesperson Adaptive Selling Behavior and Customer Orientation: A Meta-Analysis," Journal of Marketing Research, 43 (November), 693-702.

Frazier, G., R.Spekman, and C.O'Neal (1988), "Just-in-Time Exchange Relationships in Industrial Markets," Journal of Marketing, 52(4), 52-67.

Gatignon, Hubert and Jean-Marc Xuereb (1997), "Strategic Orientation of the Firm and New Product Performance," Journal of Marketing Research, 34 (February), 77-90. 
Gauzente (1999), "Comparing Market Orientation Scales: A Content Analysis," Marketing Bulletin, 10(May), 76-82.

Goff B.G., J.S.Boles, D.N.Bellenger, and C.Stojack (1997), "The Influence of Salesperson Selling Behaviors on Customer Satisfaction with Products," Journal of Retailing, 73(2):171-83.

Germain, R., C.Droge, and P.J.Daughtery (1994), "The Effect of Just-in-Time Selling on Organizational Structure: An Empirical Investigation," Journal of Marketing Research, 31(4), 471-483.

Gray, B., Matear, S., Boshoff, C., and P. Matheson. (1998), "Developing a Better Measure of Market Orientation," European Journal of Marketing, 32, 9-10, 884-903.

Green, Kenneth W. Jr., R. Anthony Inman, and Gene Brown (2008), “Just-In-Time Selling Construct: Definition and Measurement," Industrial Marketing Management, 37 (2), 131-142.

Greenblatt, S. (1993), "Continuous Improvement in Supply Chain Management," Chief Executive, 86, 40-43.

Grönroos, C. (1993), Strategic Management and Marketing in the Service Sector, Chartwell-Bratt, London.

Grönroos, C. (1991), "The Marketing Strategy Continuum: Toward a Marketing Concept," Services Marketing Management Decision, 29 (1), 7-13.

Gwinner, R. (1968), "Base Theory in the Formulation of Sales Strategies," MSU Business Topics, 16 (Autumn), 37-44.

Harris, Eric G, John C Mowen, and Tom J Brown(2005), "Re-examining Salesperson Goal Orientations: Personality Influencers, Customer Orientation, and Work Satisfaction," Journal of the Academy of Marketing Science,33(1),19-35.

Hartline, M.D., J.G.Maxham III, and D.O.McKee (2000), "Corridors of Influence in the Dissemination of Customer-Oriented Strategy to Customer Contact Service Employees", Journal of Marketing, 64(2), 35-50.

Harvey, M., and M.M.Novicevic (2001), "Selecting Expatriates for Increasingly Complex Global Assignments," Career Development International, 62,369-87.

Hinkin, Timothy R. (1995), "A Review of Scale Development Practices in the Study of Organizations," Journal of Management, 21(5), 967-988.

Hoffman, Douglas K., and Thomas N. Ingram (1991),"Creating Customer-Oriented Employees: The Case in Home Health Care," Journal of Human Capacity Management, $11(2), 24-32$.

Hogan, J., R.Hogan, and C.M.Busch (1984), "How to Measure Service Orientation", Journal of Applied Psychology, 69(1), 167-73. 
Hogan, R. T. (1983), “A Socioanalytic Theory of Personality,” In M. Page (Ed.), 1982 Nebraska Symposium on Motivation (pp. 55-89). Lincoln: University of Nebraska Press.

Howe, Vince K., Douglas Hoffman, and Donald W.Hardigree (1994), "The Relationship between Ethical and Customer-Oriented Service Provider Behaviors," Journal of Business Ethics, 13(7), 497-506.

Jaramillo, Fernando, Daniel M. Ladik, Greg W. Marshall, and Jay Prakash Mulki (2007), "A Meta-Analysis of the Relationship between Sales Orientation-Customer Orientation (SOCO) and Salesperson Job Performance," Journal of Business \& Industrial Marketing, 22(5), 302-310.

Jayachandran, S., S.Sharma, P.Kaufman, and P.Raman (2005), "The Role of Relational Information Processes and Technology Use in Customer Relationship Management," Journal of Marketing, 69(4), 177-92.

John, O. P. (1990), "The "Big Five" Factor Taxonomy: Dimensions of Personality in the Natural Language and in Questionnaires," In L. A.Pervin (Ed.), Handbook of Personality: Theory and Research (pp. 66-100). New York: Guilford Press.

Jones, Eli, Paul Busch, and Peter Dacin (2003), "Firm Market Orientation and Salesperson Customer Orientation: Interpersonal and Intrapersonal Influences on Customer Service and Retention in Business-to-Business Buyer-Seller Relationships," Journal of Business Research, 56 (4), 323-340.

Jordan, J., and S.Cartwright (1998), "Selecting Expatriate Managers: Key Traits and Competencies," Leadership \& Organization Development Journal, 19(2), 89-96.

Joshi, Ashwin W., and Sheila Randall (2001), "The Indirect Effects of Organizational Controls on Salesperson Performance and Customer Orientation," Journal of Business Research, 54(1), 1 - 9.

Kelley S.W. (1992), "Developing Customer Orientation among Service Employees," Journal of the Academy of Marketing Science, 20(Winter):27-36.

Kennedy, Karen N., Felicia G. Lassk, and Jerry R. Goolsby (2002),"Customer Mind-Set of Employees throughout the Organization," Journal of the Academy of Marketing Science, 30 (2), 159-171.

Kohli, Ajay K, and Bernard J, Jaworski (1990), "Market Orientation: The Construct, Research Propositions, and Managerial Implications," Journal of Marketing, 54 (April), $1-18$.

and Ajith Kumar (1993), "MARKOR: A Measure of Market Orientation," Journal of Marketing Research, 30 (November), 467-77.

Kohli, Ajay, Tasadduq A. Shervani, and Goutam M. Challagalla (1998), "Learning and Performance Orientation of Salespeople: The Role of Supervisors," Journal of Marketing Research, 35 (May), 263-274. 
Kotler, P. (1980), Marketing Management: Analysis, Planning and Control, 4th Ed. Englewood Cliffs, NJ: Prentice-Hall, Inc.

Kurtz, D. L., H. R. Dodge, and J. E. Klompmaker (1976), Professional Selling. Dallas: Business Publications Inc.

Lado, N., Olivares, A.M., and J. Rivera, (1998), "Measuring Market Orientation in Several Populations,” European Journal of Marketing, 32, 1-2 23-39.

Lafferty, Barbara A., and G. Tomas M.Hult (2001), "A Synthesis of Contemporary Market Orientation Perspectives," European Journal of Marketing, 35(1/2), 92-109.

Langerak F. (2001), "Effects of Market Orientation on the Behavior of Salespersons and Purchasers, Channel Relationships, and Performance of Manufacturers," International Journal of Research in Marketing, 18:221-34.

Leigh, Thomas W., and Patrick F. McGraw (1989), "Mapping the Procedural Knowledge of Industrial Sales Personnel: A Script Theoretic Investigation," Journal of Marketing, 53(1), 16-34.

Levitt, T. (1960), "The Industrialization of Service," Harvard Business Review, September/October, 41-52.

Lichtenstein, Edward H. and William F.Brewer (1980), "Memory for Goal-Directed Events," Cognitive Psychology, 12(July),412-45.

Loevinger, J. (1957), "Objective Tests as Instruments of Psychological Theory, "Psychological Reports, 3, 635-694.

Lofquist, L. H., and R.V.Dawis (1978), "Values as Second-Order Needs in the Theory of Work Adjustment," Journal of Vocational Behavior, 12, 12-19.

Lytle, Richard S., Peter W.Hom, and Michael P. Mokwa (1998), "SERV*OR: A Managerial Measure of Organizational Service-Orientation," Journal of Retailing, 74(4), 455-489.

McGuire, W. J. (1989), "The Structure of Individual Attitudes and Attitude Systems," In A. R. Pratkanis, S. J. Breckler, \& A. G.Greenwald (Eds.), Attitude Structure and Function ( pp. 37-68).Hillsdale, NJ: Erlbaum.

Mengüç, Bülent (1996),"The Influence of the Market Orientation of the Firm on Sales Force Behavior and Attitudes: Further Empirical Results," International Journal of Research in Marketing, 13 (3), 277-291.

Michaels, R. E., and R.L.Day (1985), "Measuring Customer Orientation of Salespeople: A Replication with Industrial Buyers," Journal of Marketing Research, 22(4), 443-446.

Mortimer, J. (1975), "Occupational Value Socialization in Business and Professional Families," Sociology of Work and Occupations, 2, 29-53. 
Mowen, John C. and Nancy Spears (1999), "A Hierarchical Model Approach to Understanding Compulsive Buying Among College Students," Journal of Consumer Psychology, 8 (4), 407-30.

Narver, J. and S. Slater (1998), "Additional Thoughts on the Measurement of Market Orientation: A Comment on Deshpande and Farley," Journal of Market Focussed Management, 2, 233-236.

Narver, John C, and Stanley F, Slater (1990), 'The Effect of a Market Orientation on Business Profitability," Journal of Marketing, 54 (October), 20-35.

Noble, C.H., K.S.Rajiv and A. Kumar (2002), "Market Orientation and Alternative Strategic Orientations: A Longitudinal Assessment of Performance Implication," Journal of Marketing, 66(4) 25-40.

Nwankwo, S. (1995), "Developing a Customer Orientation", Journal of Consumer Marketing, 12(5), 5-15.

O'Hara B.S., J.S.Boles, and M.W.Johnston (1991), "The Influence of Personal Variables on Salesperson Selling Orientation," Journal of Personal Selling and Sales Management, 11(Winter), 61-67.

Peccei, Riccardo and Patrice Rosenthal (1997),"The Antecedents of Employee Commitment to Customer Service: Evidence from a UK Service Context," International Journal of Human Resource Management, 8 (1), 66-86.

and (2000),"Front-Line Responses to Customer Orientation Programs: A Theoretical and Empirical Analysis," International Journal of Resource Management, 11 (3), 562-590.

Pelham, A. M. (1997), "Mediating Influences on the Relationship between Market Orientation and Profitability in Small Industrial Firms," Journal of Marketing Theory and Practice, 24, 1, 27-43.

Periatt, Jeffery, Stephen A. LeMay, and Subhra Chakrabarty (2004), "The Selling Orientation-Customer Orientation (SOCO) Scale: Cross-Validation of the Revised Version," Journal of Personal Selling \& Sales Management, 24, 1 (Winter), 49-54.

Pryor, Robert G. (1987), "Differences among Differences: In Search of General Work Preference Dimensions," Journal of Applied Psychology, 72(3), 426-33.

Pryor, R. G. (1983b). Manual for the Work Aspect Preference Scale. Melbourne: Australian Council for Education Research.

Pryor, R. G. (1982), "Values, Preferences, Needs, Work Ethics and Orientations to Work: Toward a Conceptual and Empirical Integration," Journal of Vocational Behavior, 20, $40-52$. 
Pryor, R. G. (1982), "Values, Preferences, Needs, Work Ethics and Orientations to Work: Toward a Conceptual and Empirical Integration," Journal of Vocational Behavior,20, 4052 .

Pryor, R. G. (1979), "In Search of a Concept: Work Values," Vocational Guidance Quarterly, 27, 250-258.

Ray, John J. (1973), “Task Orientation and Interaction Orientation Scales," Personnel Psychology, 26, 61-73.

Reicheld F.F, and W.E.Sasser (1990), "Zero Defections: Quality Comes to Services," Harvard Business Review, 68(September-October):105 -11.

Rossiter, John R. (2002), "The C-OAR-SE Procedure for Scale Development in Marketing," International Journal of Research in Marketing, 19,305-335.

Ruekert, R.W. (1992) "Developing a Market Orientation: An Organizational Strategy Perspective," International Journal of Research in Marketing, 9, 225-245.

Saxe, Robert, and Barton A Weitz (1982), "The SOCO Scale: A Measure of the Customer Orientation of Salespeople,” Journal of Marketing Research, 19 (3), 343-351.

Scheibelhut J.H., and G.Albaum (1973), "Self-other Orientations among Salesmen and Non-salesmen," Journal of Marketing Research, 10(February), 97-99

Schmitt, N.W., and D.M.Stults (1985), "Factors Defined by Negatively Keyed Items: The Results of Careless Respondents?," Applied Psychological Measurement, 9: 367-373.

Sethi, Vijay, and William R. King (1994), "Development of Measures to Assess the Extent to Which an Information Technology Application Provides Competitive Advantage, Management Science, 40(12), 1601-1627.

Shapiro, B. (1988), "What the Hell is Market Oriented?" Harvard Business Review (November/December), 119-25.

Siguaw J.A., and E.D.Honeycutt (1995), "An Examination of Gender Differences in Selling Behaviors and Job Attitudes," Industrial Marketing Management, 24(January), $45-52$.

Sin, Leo Y.M., Alan C.B. Tse, Oliver H.M. Yau, Raymond P.M. Chow, Jenny S.Y. Lee, and Lorett B.Y.Lau (2005), "Relationship Marketing Orientation: Scale Development and Cross-Cultural Validation,” Journal of Business Research, 58(2), 185- 194.

Sin, Y.M., C.B. Tse, H.M. Yau, R. Chow, and S.Y. Lee (2002), "The Effect of Relationship Marketing Orientation on Business Performance in a Service-Oriented Economy," Journal of Services Marketing, 16 (7), 656-76.

Slater, S F., and J.C. Narver (1995), "Market Orientation and the Learning Organization," Journal of Marketing, 59(3), 63-74. 
Solomon, Michael R., Carol Surprenant, John A.Czepiel, and Evelyn G.Gutman (1985), "A Role Theory Perspective on Dyadic Interactions: The Service Encounter," Journal of Marketing, 49(Winter), 99-111.

Stock, R.M. and Hoyer, W.D. (2005), “An Attitude-Behavior Model of Salespeople's Customer Orientation", Journal of the Academy of Marketing Science, 33(4),536-52.

Standards for Educational and Psychological Testing (1985), Washington, DC: American Psychological Association.

Strong, E. K., Jr. (1925), "Theories of Selling," Journal of Applied Psychology, 9 (January), 75-86.

Sujan, Harish (1986), "Smarter Versus Harder: An Exploratory Attributional Analysis of Salespeople's Motivation,” Journal of Marketing Research, 23(February), 41-49.

Sujan, Harish, Barton A. Weitz, and Nirmalya Kumar (1994), "Learning Orientation, Working Smart, and Effective Selling,” Journal of Marketing 58 (July), 39-52.

Tadepalli, Raghu (1995),"Measuring Customer Orientation of a Salesperson: Modifications of the SOCO Scale," Psychology \& Marketing, 12 (3) (May), 177-187.

Thomas, K. W. (1976), "Conflict and Conflict Management," in Handbook of Industrial and Organizational Psychology. D. Dunnette, Ed. Chicago: Rand-McNally.

Thomas, Raymond W., Geoffrey N.Soutar, and Maria M Ryan (2001), "The Selling Orientation-Customer Orientation (S.O.C.O.) Scale: A Proposed Short Form," Journal of Personal Selling \& Sales Management, 21(1), 63-69.

Van Seters, D. A., and H.G.Field (1990), “The Evolution of Leadership Theory," Journal of Organizational Change Management, 3(3), 29-45.

Vandewalle, Donald, Steven P. Brown, William L. Cron, and John W. Slocum (1999), "The Influence of Goal Orientation and Self-Regulation Tactics on Sales Performance: A Longitudinal Field Test," Journal of Applied Psychology, 84 (2), 249-259.

Vandewalle, Donald, and Larry L. Cummings (1997), "A Test of the Influence of Goal Orientation on the Feedback-Seeking Process," Journal of Applied Psychology, 82 (3), 390-400.

Watson, D., L.A.Clark, and A.R.Harkness (1994), "Structures of Personality and their Relevance to Psychopathology," Journal of Abnormal Psychology, 103, 18-31.

Webster Jr., F. E. (1992), "Changing Role of Marketing in the Corporation," Journal of Marketing, 56(October), $1-17$.

Webster, F.E. (1988), "The Rediscovery of the Marketing Concept”, Business Horizons (May/June), 29-39 
Weitz, Barton A. (1979), "A Critical Review of Personal Selling Research: The Need for Contingency Approaches," in Critical Issues in Sales Management: State-of-the-Art and Future Research Needs, Gerald Albaum and Gilbert A.Churchill, Jr. Eds. Eugene: College of Business Administration, University of Oregon, 76-126.

Widmier, Scott (2002), "The Effects of Incentives and Personality on Salesperson's Customer Orientation,” Industrial Marketing Management, 31(7), 609-615.

Williams, M.R. and Wiener, J. (1990), "Does the Selling Orientation-Customer Orientation (SOCO) Scale Measure Behavior or Disposition?," in Bearden, W., Despande', T.J., Madden, P.R. and Varadarajan, A. (Eds), Enhancing Knowledge Development in Marketing, American Marketing Association, Chicago, IL. 


\section{APPENDIX}

\section{SOCO (Selling Orientation-Customer Orientation) Scale (Saxe and Weitz 1982)}

\section{INSTRUCTIONS:}

The statements below describe various ways a salesperson might act with customer or prospect (for convenience, the word "customer" is used to refer to both customers and prospects). For each statement please indicate the proportion of your customers with whom you act as described in the statement. Do this by circling one of the numbers from 1 to 9 , The meanings of the numbers are:

1-True for NONE of your customers-NEVER

2-True for ALMOST NONE

3-True for A FEW

4-True for SOMEWHAT LESS THAN HALF

5-True for ABOUT HALF

6-True for SOMEWHAT MORE THAN HALF

7-True for a LARGE MAJORITY

8-True for ALMOST ALL

9-True for ALL of your customers-ALWAYS

\section{Stem—positively stated items}

1. I try to help customers achieve their goals.

2. I try to achieve my goals by satisfying customers.

3. A good salesperson has to have the customer's best interest in mind.

4. I try to get customers to discuss their needs with me.

5. I try to influence a customer by information rather than by pressure.

6. I offer the product of mine that is best suited to the customer's problem.

7. I try to find out what kind of product would be most helpful to a customer.

8. I answer a customer's questions about products as correctly as I can.

9. I try to bring a customer with a problem together with a product that helps him solve that problem.

10. I am willing to disagree with a customer in order to help him make a better decision. 
11. I try to give customers an accurate expectation of what the product will do for them.

12. I try to figure out what a customer's needs are.

Stem-negatively stated items

13. I try to sell a customer all I can convince him to buy, even if I think it is more than a wise customer would buy.

14. I try to sell as much as I can rather than to satisfy a customer.

15. I keep alert for weaknesses in a customer's personality so I can use them to put pressure on him to buy.

16. If I am not sure a product is right for a customer, I will still apply pressure to get him to buy.

17. I decide what products to offer on the basis of what I can convince customers to buy, not on the basis of what will satisfy them in the long run.

18. I paint too rosy a picture of my products, to make them sound as good as possible.

19. I spend more time trying to persuade a customer to buy than I do trying to discover his needs.

20. It is necessary to stretch the truth in describing a product to a customer.

21. I pretend to agree with customers to please them.

22. I imply to a customer that something is beyond my control when it is not.

23. I begin the sales talk for a product before exploring a customer's needs with him.

24. I treat a customer as rival.

\section{MARKOR (Kohli, Jaworski, and Kumar 1993)}

Likert scale type (1 to 5) with "strongly disagree," “disagree," “"neither agree nor disagree," "agree," and "strongly agree", as the alternative choices.

\section{Intelligence generation}

1. In our business unit, we meet with customers at least once a year to find out what products or services they will need in the future. 
2. Individuals from our service department interact directly with customers to learn how to serve their needs better.

3. In our business unit, we do a lot of in-house market research.

4. We are slow to detect changes in our customers' product/service preferences $(R)$.

5. We survey end-users at least once a year to assess the quality of our product and service offerings.

6. We often share our survey results with those who can influence our end-users' purchase such as retailers and distributors.

7. We collect industry information by informal means (e.g., lunch with industry friends, talk with trade partners).

8. In our business unit, market intelligence on our competitors is generated independently by several departments of our firm.

9. We are slow to detect fundamental shifts and trends in our industry such as competition, technology, and regulation $(\mathrm{R})$.

10. We periodically review the likely effect of changes in our business environment such as regulations and technology on customers.

\section{Intelligence dissemination}

11. A lot of informal talks in this business unit concerning our competitors' tactics or strategies.

12. We have interdepartmental meetings at least once a quarter to discuss market trends and developments.

13. Marketing personnel in our business unit spend time discussing customers' future needs with other functional departments.

14. Our business unit periodically circulates documents (e.g., reports, and newsletters) that provide information on our customers.

15. When something important happens to our major customer of market, the whole business unit knows about it within a short period.

16. Data on customer satisfaction are disseminated at all levels in this business unit on a regular basis.

17. There is minimal communication between marketing and manufacturing departments concerning market developments $(\mathrm{R})$.

18. When one department finds out something important about competitors, it is slow to alert other departments $(\mathrm{R})$. 


\section{Responsiveness}

19. It takes us forever to decide how to respond to our competitor's price changes (R).

20. In our business unit, principles of market segmentation drive new product development efforts.

21. For one reason or another we tend to ignore changes in our customer's product/service needs $(\mathrm{R})$.

22. We periodically review our product development efforts to endure that they are in line with what customers want.

23. Our business plans are driven more by technological advances than by market research $(\mathrm{R})$.

24. Several departments get together periodically to plan a response to changes taking place in our business environment.

25. The product/service lines we market depend more on internal politics than real market needs $(\mathrm{R})$.

26. If a major competitor were to lunch an intensive campaign targeted at our customers, we would implement a response immediately.

27. The activities of the different departments in this business unit are well coordinated.

28. Customer complaints fall on deaf ears in this business unit (R).

29. Even if we came up with a great marketing plan, we probably would not be able to implement it in a timely fashion (R).

30. We are quick to respond to significant changes in our competitors' pricing structures.

31. When we find out that customers are unhappy with quality of our service, we take corrective action immediately.

32. When we find that customers would like us to modify a product or service, the departments involved make concerted efforts to do so.

\section{MKTOR (Narver and Slater 1990)}

7-point Likert scale with a 1 indicating that the business unit does not engage in the practice at all and a 7 indicating that it engages in it to a very great extent. 


\section{Customer Orientation}

1. Customer commitment

2. Create customer value

3. Understand customer needs

4. Customer satisfaction objectives

5. Measure customer satisfaction

6. After-sales service

\section{Competitor Orientation}

7. Salespeople share competitor information

8. Respond rapidly to competitors' actions

9. Top managers discuss competitors' strategies

10. Target opportunities for competitive advantage

\section{Interfunctional Coordination}

11. Interfunctional customer calls

12. Information shared among functions

13. Functional integration in strategy

14. All functions contribute to customer value

15. Share resources with other business units

\section{Long-Term Horizon}

16. Quarterly profits are primary objective

17. Require rapid payback

18. Positive margin in long term

\section{Profit Emphasis}

19. Profit performance measured market by market

20. Top managers emphasize market performance

21. All products must be profitable 


\section{Market Orientation Scale (Gray et al 1998)}

\section{Customer Orientation (CUSTOR)}

1. We encourage customer comments and complaints because they help us do a better job

2. After-sales service is an important part of our business strategy

3. We have a strong commitment to our customers

4. We are always looking at ways to create customer value in our products

5. We measure customer satisfaction on a regular basis

\section{Competitor Orientation (COMPOR)}

6. We regularly monitor our competitors' marketing efforts

7. We frequently collect marketing data on our competitors to help direct our marketing plans

8. Our salespeople are instructed to monitor and report on competitor activity

\section{Interfunctional Co-ordination (FUNCOP)}

9. Marketing information is shared with all departments

10. We regularly have inter-departmental meetings to discuss market trends and developments

11. Our marketing people regularly discuss customer needs with other departments

12. The marketing people regularly interact with other departments on a formal basis

13. All departments are involved in preparing business plans/strategies

14. We do a good job integrating the activities of all departments

\section{Responsiveness (RESPDE)}

15. We are quick to respond to significant changes in our competitors' pricing

16. Somehow we tend to ignore changes to our customers' product/service needs (negative values indicate greater responsiveness) 


\section{Profit emphasis (PROFEMP)}

17. Our management information system can quickly determine the profitability of our major customers

18. Our management information system can quickly determine the profitability of our product lines

19. Our management information system can quickly determine the profitability of our sales territories

20. Our management information system can quickly determine the profitability of our distribution channels

\section{Market Orientation Scale (Lado, Olivares and Rivera 1998)}

\section{Analysis of the final client}

1. We systematically and frequently measure customer satisfaction.

2. We periodically analyze our customers' current and future needs.

3. We regularly examine the factors influencing the buying decisions of our customers.

4. We regularly collect market information to detect the emergence of new segments

5. We periodically measure the customers' image of our product/service

6. We develop a monitoring of the changes in preferences of our customers' system

\section{Analysis of the distributor}

7. We systematically and frequently measure distributor satisfaction

8. We regularly examine the current needs of our distributors

9. We analyse the compatibility of our marketing strategy with the objectives of our distributors

10. We systematically analyse the problems that our distributors can have with the marketing of our products 
11. We regularly measure the distributors' image of our firm

\section{Analysis of the competitors}

12. We analyse our competitor strategies systematically and regularly

13. We systematically examine the strengths/weaknesses of our competitors

14. We frequently monitor competitor marketing variables (price, product, promotion, market)

15. We regularly analyse the evolution of substitute products/services

\section{Analysis of the environment}

16. We systematically evaluate the impact of the environment on our customers

\section{Interfunctional co-ordination}

17. Market information is diffused systematically and regularly to all functions of the firm

18. Market strategies are developed by all organizational functions in a co-ordinated manner

19. Organizational decisions are executed with a sense of personal commitment to serve the market

20. We systematically organize meetings between the different functions to analyse market information

21. We stimulate an informal information exchange between the different functions of the firm

\section{Strategic actions on final customers}

22. We market products/services that adequately satisfy the final customers' current needs

23. We systematically market innovative products/services 
24. We are faster than the competitors to respond to the changes of our final customers' needs

25. We rapidly implement the marketing plan

26. We develop strategies to diminish the (monetary and psychological) costs of acquiring our products

27. We inform our final customers on the diverse ways to obtain a better benefit from our products/services

\section{Strategic actions on intermediary customers (distributors)}

28. The managers are very committed in the firm's contact with its distributors

29. Distributors are recognized as partners in serving end-users

30. We constantly share information on our marketing strategies with our distributors

31. We develop strategies to stress the benefits that distributors obtain from maintaining their relations with our firm

32. We rapidly react to satisfy our distributors' complaints

\section{Strategic actions on competitors}

33. We are faster to respond to competitors' actions directed at our final customers

34. We are faster to respond to competitors' actions directed at our distributors 39

\section{Strategic actions on the macro-environment}

35. We develop strategies to influence the key groups of the macro-environment (consumers' associations, political groups)

36. We undertake systematic activities to stress the benefits that the firm gives to the society in general 


\section{Market Orientation Summary Scale (Deshpande and Farley 1996)}

Respondents asked to indicate the extent to which they agree with each statement on a 7point Likert scale with anchors 1 = "strongly disagree" and 7 = "strongly agree."

1. Our business objectives are driven primarily by customer satisfaction.

2. We constantly monitor our level of commitment and orientation to serving customer needs.

3. We freely communicate information about our successful competitor experiences across all business functions.

4. Our strategy for competitive advantage is based on our understanding of customers' needs.

5. We measure customer satisfaction systematically and frequently.

6. We have routine or regular measures of customer service.

7. We are more customer-focused than our competitors.

8. I believe this business exists primarily to serve customers.

9. We poll end-users at least once a year to assess the quality of our products and services.

10. Data on customer satisfaction are disseminated at all levels in this business unit on a regular basis.

\section{Customer Orientation (Brown ET al.2002)}

9-point Likert scale with verbal anchors ranging from "strongly disagree" to "strongly agree".

\section{Enjoyment dimension}

1.I find it easy to smile at each of my customers.

2.I enjoy remembering my customers' names.

3.It comes naturally to have empathy for my customers.

4.I enjoy responding quickly to my customers' requests.

5.I get satisfaction from making my customers happy.

6.I really enjoy serving my customers. 


\section{Needs dimension}

7.I try to help customers achieve their goals.

8.I achieve my own goals by satisfying customers.

9.I get customers to talk about their service needs with me.

10. I take a problem-solving approach with my customers.

11. I keep the best interests of the customer in mind.

12. I am able to answer a customer's questions correctly.

\section{Salespeople's learning orientation (Sujan, Weitz, and Kumar's 1994)}

1. There really aren't a lot of new things to learn about selling (R)

2. It is worth spending a lot of time learning new approaches for dealing with customers.

3. An important part of being a salesperson is continually improving your sales skills.

4. I put in a great deal of effort in order to learn something new about selling.

5. It is important for me learn from each selling experience I have.

6. Learning how to be a better salesperson is of fundamental importance to me.

\section{Salespeople's performance orientation (Sujan, Weitz, and Kumar's 1994)}

1. I spend a lot of time thinking about how my performance compares with that of other salespeople.

2. I evaluate myself using my supervisor's criteria.

3. I always try to communicate my achievements to my manager

4. I feel very good when I know I have outperformed other salespeople in my company.

5. It is very important that my manager sees me as a good salesperson. 


\section{Customer Orientation (Deshpande, Farley and Webster 1993)}

The statements below describe norms that operate in businesses. Please indicate your extent of agreement about how well the statements describe the actual norms in your business.

1. Strongly Disagree

2. Disagree

3. Neither Agree Nor Disagree

4. Agree

5. Strongly Agree

Instruction: Answer in the context of your specific product/ market or service/market business

1. We have routine or regular measures of customer service.

2. Our product and service development is based on good market and customer information.

3. We know our competitors well.

4. We have a good sense of how our customers value our products and services.

5. We are more customer focused than our competitors.

6. We compete primarily based on product or service differentiation.

7. The customer's interest should always come first, ahead of the owners'.

8. Our products/services are the best in the business.

9. I believe this business exists primarily to serve customers.

\section{Work Aspect Preference Subscales (WAPS) (Pryor 1983b)}

Independence

CoWorkers

Self-Development

Creativity
A concern for being free from imposed constraints in the work environment

A concern for friendship and understanding from those with whom one works

A concern for developing and using one's skills and abilities

A concern for developing something original through one's work 
Money

Life Style

Prestige

Altruism

Security

Management

Detachment

Physical Activity

Surroundings
A concern for obtaining large financial rewards from one's work

A concern for the effect that employment may have on where and how one lives

A concern for recognition and status in the eyes of others

A concern for assisting others

A concern for being able to maintain one's job

A concern for organizing the work of others

A concern for being able to separate work and its influence from other parts of one's life A concern for being physically active in one's work A concern for the kind of physical environment in which one works

\section{Balanced Task-Orientation Scale (Ray 1973)}

Positive Items Scored from Five ("Strongly Agree") to One ("Strongly Disagree"). A Midpoint scored three ("Not sure") is allowed. Negative Items (Marked R) are ReverseScored.

1. I don't like having to take time off work.

2. You can't succeed in business without really trying.

3. If I won the lottery I would never work again.(R)

4. This country should introduce a four-day working week. (R)

5. Schools should place more emphasis on teaching children to follow through on a job.

6. Never do today what you can put off till tomorrow. (R)

7. I am happiest when I am doing nothing. (R)

8. Ambition is essential in leadership.

9. Work is the root of all evil. (R) 
10. Hard work takes the enjoyment out of life. (R)

11. The camel looks like an animal designed by a committee.

12. There should be more public holidays. (R)

13. If I had more time I would like to work at my hobby or learn something new and interesting.

14. Work is a bore. $(\mathrm{R})$

15. Outdated methods must be eliminated in spite of people's feeling.

16. I have no motivation for accomplishment. (R)

17. If at first you don't succeed try, try again.

18. I generally drift with the crowd. (R)

19. Ambition is a stain on the human spirit. (R)

20. Know-how and initiative are the most important qualities a person can have.

21. I don't want to get on in life. (R)

22. Sentiment should not stand in the way of progress.

23. The best instructors make their pupils work harder by stimulating their curiosity about the subject.

24. I don't do any more work than I can get out of. (R)

25. The best thing about work is the knock-off whistle. (R)

26. Workers should concentrate on getting the job done.

27. The best hobby is one that produces tangible results.

28. I am happiest when I am getting things done.

29. The satisfaction I get from my performance is the main thing for me in anything I undertake.

30. Work is always something that is best avoided if you can. (R)

31. Overwork is the cause of a lot of ill-health today. (R)

32. The newspapers never give enough space to people who complete worthwhile projects.

33. If a job is worth doing, it is worth doing well.

34. Starting things is much more enjoyable than finishing them. (R)

35. Washing the car is generally a waste of energy. (R)

36. I look forward to the day when all work will be done by robots. (R)

37. People should keep themselves busy with some hobby during their leisure time.

38. I never enjoy anything I have to do in order to earn my living. (R)

39. The greatest satisfaction in life for me is the feeling of a job well done. 
40. We should always persevere until we accomplish what we set out to do.

\section{$\underline{\text { Relationship Marketing Orientation Scale (Sin et al. 2005) }}$}

Instruction: The following sentences describe the relationship between your company and your company's major customers. Please circle the most appropriate number on a scale of 1-7, after the following sentences according to your opinions. (The word "they" indicates the customers with whom you are in contact.)

\section{Trust}

1. We trust each other.

2. They are trustworthy on important things.

3. According to our past business relationship, my company thinks that they are trustworthy persons.

4. My company trusts them.

\section{Bonding}

1. We rely on each other.

2. We both try very hard to establish a long-term relationship.

3. We work in close cooperation.

4. We keep in touch constantly.

\section{Communication}

1. We communicate and express our opinions to each other frequently.

2. We can show our discontent towards each other through communication.

3. We can communicate honestly.

\section{Shared value}

1. We share the same worldview.

2. We share the same opinion about most things.

3. We share the same feelings toward things around us. 
4. We share the same values.

\section{Empathy}

1. We always see things from each other's view.

2. We know how each other feels.

3. We understand each other's values and goals.

4. We care about each other's feelings.

\section{Reciprocity}

1. My company regards “"never forget a good turn" as our business motto.

2. We keep our promises to each other in any situation.

3. If our customers gave assistance when my company had difficulties, then I would repay their kindness.

\section{Relationship Marketing Orientation (RMO) Scale (Camarero 2007)}

5-point Likert questions (ranging from 1= "completely disagree with the item" to $5=$ "completely agree with the item").

\section{Customization}

1. The company has flexibility to adapt the offer to the needs and requests of each customer

2. The terms of a contract or repetitive transactions could be renegotiate in case an unexpected situation occurred

3. We have made important investments in the development of products adapted to each customer

\section{Communication}

4. We maintain fluid and frequent communication with our customers

5. The communication with customers is valued by them

6. The communication is bi-directional 
7. We send regularly mails to our customers with personalized information which has interest to them

\section{Preferential treatment - personalization (formative scale)}

8. We make greater investments (time, human resources and other actives) to regular customers than to non regular customers.

9. We make greater investments (time, human resources and other actives) to customers with greater volume of trade than to customers less important.

10. We offer a better service to regular customers and with greater volume of trade

11. The company offers economic benefits to customers more frequent and with greater volume of trade.

12. We offer more information to regular customers and with greater volume of trade than to others.

13. We contact more frequently with regular customers and with greater volume of trade than with others.

\section{Personal Relationships}

14. We foster the development of personal relationships with our customers.

15. Our employees maintain close relationships with our customers.

\section{Service Quality Orientation Scale (Grönroos 1993)}

5-point Likert questions (ranging from $1=$ "completely disagree with the item" to $5=$ "completely agree with the item").

1. The company offers the best technologies as material support to the services

2. Branch offices have an image of professionalism

3. The company offers the greatest quality in every service

4. The employees are trained to provide correctly the services to customers

5. The customers receive an efficient service by our employees 


\section{SERV*OR Scale (Lytle et al 1998)}

\section{Customer Treatment}

1. Employees care for customers as they would like to be cared for.

2. Employees go the "extra mile" for customers.

3. We are noticeably more friendly and courteous than our competitors.

4. Employees go out of their way to reduce inconveniences for customers.

\section{Employee Empowerment}

5. Decisions are made "close to the customer." In other words, employees often make important customer decisions without seeking management approval

6. Employees have freedom and authority to act independently in order to provide excellent service

\section{Service Technology}

7. We enhance our service capabilities through the use of "state of the art" technology.

8. Technology is used to build and develop higher levels of service quality.

9. We use high levels of technology to support the efforts of men and women on the front line.

\section{Service Failure Prevention}

10. We go out of our way to prevent customer problems.

11. We go out of our way to "head off or prevent customer problems rather than reacting to problems once they occur.

12. We actively listen to our customers.

\section{Service Failure Recovery}

13. We have an excellent customer complaint handling system for service follow-up

14. We have established problem-solving groups to enhance our ability to resolve service breakdowns.

15. We provide follow-up service calls to confirm that our services are being provided properly. 
16. We provide every customer with an explicit service guarantee

\section{Service Standards Communication}

17. We do not wait for customers to complain, we use internal standards to pinpoint failures before we receive customer complaints

18. Every effort is made to explain the results of customer research to every employee in understandable terms.

19. Every employee understands all of the service standards that have been instituted by all departments.

20. We have a developed chain of objectives linking together every branch in support of the corporate vision.

21. Service performance measures are communicated openly with all employees regardless of position or function.

\section{Service Vision}

22. There is a true commitment to service, not just lip service.

23. Customers are viewed as opportunities to serve rather than as sources of revenue.

24. It is believed that fundamentally, the organization exists to serve the needs of its customers.

\section{Servant Leadership}

25. Management constantly communicates the importance of service.

26. Management regularly spends time "in the field" or "on the floor" with customers and front-line employees.

27. Management is constantly measuring service quality.

28. Management shows that they care about service by constantly giving of themselves.

29. Management provides resources, not just "Lip service" to enhance employee ability to provide excellent service.

30. Managers give personal input and leadership into creating quality service

\section{Service Rewards}

31. Management provides excellent incentives and rewards at all levels for service quality, not just productivity. 
32. This organization noticeably celebrates excellent service.

\section{Service Training}

33. Every employee receives personal skills training that enhance his/her ability to deliver high quality service.

34. We spend much time and effort in simulated training activities that help us provide higher levels of service when actually encountering the customer.

35. During training sessions we work through exercises to identify and improve attitudes toward customers.

\section{JIT-Selling (Green et al. 2008)}

\section{Single-Source Relationships Scale (SSR)}

Respondents asked to indicate the extent to which they agree with each statement on a 7point Likert scale with anchors 1 = "strongly disagree" and 7 = "strongly agree."

1. This organization's sales representatives work hard to build strong, long-term relationships with customers.

2. This organization's sales representatives work hard to build single-source relationships with customers.

3. This organization's sales representatives are directly involved in the new product design and introduction efforts of its major customers.

\section{Purchasing Process Integration Scale (PPI)}

4. This organization has dedicated full-time, on-site sales representatives to its major customers.

5. This organization's sales representatives are directly involved in the replenishment decisions of our major customers.

6. This organization's sales representatives have electronic access to the product flow and product demand information of its major customers.

7. This organization's customers provide sales representatives with relatively precise and timely demand and delivery schedules. 


\section{Product and Service Quality Scale (PSQ)}

8. During the selling process, this organization's sales representatives build value based on the zero-defect, zero-variance capabilities of this organization.

9. During the selling process, this organization's sales representatives build value based on this organization's ability to deliver value-added services associated with its products.

10. During the selling process, this organization's sales representatives build value based on this organization's ability to eliminate late, damaged and incomplete orders.

11. During the selling process, this organization's sales representatives build value based on this organization's ability to quickly respond to and resolve customer problems.

12. During the selling process, this organization's sales representatives build value based on the on-time delivery capability of this organization.

13. During the selling process, this organization's sales representatives build value based on this organization's ability to minimize total product cost.

14. During the selling process, this organization's sales representatives build value based on this organization's ability to minimize all types of waste.

\section{Inventory Minimization Scale (IMIN)}

1. During the selling process, this organization's sales representatives build value based on the precise quantity delivery capability of this organization.

2. During the selling process, this organization's sales representatives build value based on this organization's ability to deliver shipments of variable size on a frequent basis.

3. During the selling process, this organization's sales representatives build value based on this organization's ability to deliver small lot sizes and shipping case sizes.

4. During the selling process, this organization's sales representatives build value based on this organization's ability to minimize channel safety stock. 


\section{$\underline{\text { Hogan Personality Index (HPI) (Hogan et al 1984) }}$}

The primary scales of the HPI are:

1. Adjustment (Emotional Stability in the Five Factor model)

2. Ambition

3. Sociability (Extraversion in the Five Factor model)

4. Likeability (Agreeableness in the Five Factor model)

5. Prudence (Conscientiousness in the Five Factor model)

6. Intellect

7. School Success (Openness to Experience in the Five Factor model).

In addition, there are six occupational scales:

1. Service Orientation

2. Stress Tolerance

3. Reliability

4. Clerical Potential

5. Sales Potential

6. Managerial Potential. 